\title{
Use of Various Methodological Approaches in the Housing Sphere
}

\author{
Mammadov Mahabbat Ashir ${ }^{1}$, Aliyev Ruslan Yusif ${ }^{2}$ \\ Azerbaijan University Architecture and Construction ${ }^{1,2}$
}

\begin{abstract}
Research is determined by the scientific need to solve theoretical and practical problems related to the development of the housing sector, namely housing and public utilities, their social and economic importance in determining the choice of the topic of the article. In developing the problems of housing development, various methodological approaches were used: housing promotion policies and demand incentive policies in order to increase the demand for housing from low-income families.
\end{abstract}

Keywords: national, local, regional, land use, housing.

\section{INTRODUCTION}

The study showed that improving the system for managing the development of the housing sector and improving the living conditions of the population during the implementation of state socio-economic policies and its individual areas (housing, land) can be the theoretical basis for adjusting the regional programs of the housing market, housing and utilities, etc. The developed methodological issues of the housing economy will allow determining the level of housing supply to the population, its growth rates for the forecast period with the achievement of the specified levels of housing stock, its growth and input. The housing sector includes housing construction, its reconstruction and modernization, engineering equipment and facilities, elements of social infrastructure, housing maintenance and repair, housing management. It is aimed at a qualitative change in the living conditions of the population. These include housing, living conditions, the level of improvement of residential buildings, favorable sanitary conditions and other factors that determine the comfort of dwellings.

In recent years, changes have occurred in the structure of the construction of apartments in residential buildings by type of property. If in 2000 for public funds allocated for the construction of apartments it was $27.9 \%$, non-state $-72.1 \%$, personal funds of the population $-34.3 \%$, in 2015 , respectively, $14.5 \%, 85.5 \%$ and $43.9 \%$.

In 2016, the State Agency for Housing was established in the republic. Its functions include the completion by 2025 of the capital reconstruction of cities, the development and improvement of their social infrastructure. After 2025, in each region of the country it is planned to create housing sectors whose competence includes providing the population with high-quality housing and social and cultural facilities. Until 2020, 10,000 new jobs are projected in the country's construction sector, which will require 900 million manat. investments both at the expense of the state and with the involvement of private construction companies (strategic roadmap, 2016).

The growth of housing construction and an increase in the volume of reconstruction, modernization and overhaul of the housing stock require improved housing and land policies. In connection with the exorbitant increase in prices for land plots of urban areas, there is a desire to increase living space due to the number of floors, which contributes to the improvement of construction equipment and the impact of high-rise buildings. On the basis of a developed country of technology, there is a gradual increase in the level of improvement of urban housing (M.I.Kovalsky 1994); (S.N.Kirilov 2005).

Saving and more intensive use of territories in urban development is an important reserve for increasing the efficiency of capital investments in construction, engineering equipment and landscaping, etc. At the present stage of urban development, intensification is the general direction in land use. It is carried out on the basis of increasing the density of development, improving architectural planning techniques and other areas of scientific and technological progress.

An important feature of construction as a branch of material production and construction products is territorial fixation. Another significant issue is the relative duration of the production cycle. To reflect these phenomena, we introduce the concept of "building land use", i.e. use of land in a certain order in connection with the construction of objects. In this case, construction companies act as land users for the period of land acquisition for construction of the object. Its 


\title{
International Advanced Research Journal in Science, Engineering and Technology
}

\author{
Vol. 6, Issue 1, January 2019
}

important tasks are the study of the structure and trends of the dynamics of land resources, the peculiarities of their use in the construction of various objects, the development and implementation of scientifically based norms for the allocation of land. In this connection, measures on a more intensive use of lands assimilated by buildings, including the improvement of their economic evaluation, are acquiring particular relevance. When designing, the necessary assessment of the level of intensity of land use for development is often not carried out, this is connected with the insufficient theoretical development of these issues.

Regulation of the effectiveness of land use in the cities of the republic is carried out with the help of administrative, market and mixed methods. Administrative regulate the basic rules of land use in the interests of the state and are aimed at preventing the mismanagement in the use of land and pollution of the environment. Market methods predetermine the amount of tax in the budget for the use of land, payments for the withdrawal of land for new construction, as well as payment of benefits for the effective use of land. Mixed methods characterize a combination of administrative and market mechanisms. They are aimed at logistical and financial support of programs for the protection of the environment, the environment and the improvement of urban land use.

Researched and formulated approaches to the development of the housing sector in the implementation of the state housing policy, namely, in the formation of a mechanism for land use and the reform of housing and communal services and the housing market; formulated national and regional characteristics of the dwelling in the republic; proposed clarifications on the terminology of the concepts of residential real estate, construction land use, real estate market, etc.

This study is aimed at solving theoretical problems, methodological and practical issues on the definition of residential real estate.

The definitions carried out relate mainly to the land and related concepts.

In theory and practice of real estate appraisal in the United States distinguish such concepts as: physical object (real estate) and legal relations (real rights) related to real estate (real property) (S. Harrison Henry, 1994).

In the literature there is no generally accepted definition of the real estate market. When they talk about the real estate market, they usually mean the activities of this market (S. Harrison, Henry, 1994).

A group of Russian experts believes that "taking into account domestic experience in real estate sales, we can assume that the real estate market is a collection of real estate transactions. Informational support for them, operations on management and financing of works in the field of real estate "(Ed. Grigorieva, 1997).

The above definitions reveal the general content of the concept "urban construction real estate", but are not fully marked. A more professional approach is to first define the general concept of the market, and then link it to the real estate market. Analyzing the experience of developed foreign countries, we can distinguish a number of approaches in the mass assessment of urban land use.

The first approach is based on the study of various opinions of expert analysts on the market value of the object. The positive side of this approach is a high enough accuracy with a lack of information, and its disadvantage is the high cost.

In the second approach, the value of the object is determined with the help of modern methods of mathematical analysis and the statistical information processing system of a significant number of similar objects. In foreign practice, the second approach is mainly used, since statistical methods allow to achieve more reliable results compared to expert assessment.

However, in our opinion, the best approach for determining the value of land tenure and urban development objects is an integrated approach based on a combination of both of the above methods. An integrated approach to determining the value of real estate objects will allow determining and economically justifying land use standards, establishing the optimal amount of land payments, and eliminating contradictions between city residents and land and landlords. Often, due to the non-regulation of land use, the narrow commercial interests of individual regions are in conflict with the macroeconomic requirements of central government agencies.

The works of foreign scientists deserve attention in terms of posing the problems of the relationship between society and nature, information on the availability and structure of land in comparison with production development volumes, as well as economic and mathematical models and methods, analyzing resources in statics and dynamics, identifying 


\title{
International Advanced Research Journal in Science, Engineering and Technology
}

\author{
Vol. 6, Issue 1, January 2019
}

direct and reverse links. However, they have a number of serious drawbacks, the main ones being the following:

The world is considered as a unified system of development, without taking into account the qualitatively new possibilities of a market economy and without identifying developed and developing countries;

- failure to take into account the achievements of scientific and technological progress and the social sphere in the development of the productive forces of society, which can be decisive in establishing the relationship between society and nature;

- the unreality of proposals on artificially slowing production, reducing the population, refusing some countries to use land in favor of other, "poor countries".

With the development of foreign countries and the growth of production, the limitations of land and other natural resources became more and more apparent. The reduction of free territories has led to a sharp increase in the value of land. The price of land in the major cities of the United States, Japan and a number of other countries is very high. In Japan, land is about 10 times more expensive than in Europe. Under these conditions, town-planning measures to increase the density and number of floors of buildings, the use of underground space to accommodate service enterprises, engineering structures, etc., are applied to save territories.

In modern conditions in developed market countries, the construction, purchase and use of housing belongs to the sphere of private business. In a number of countries, including in Azerbaijan, state bodies and municipalities participate in housing construction. But the state bodies are mostly not engaged in construction, but are trying to influence the solution of the housing problem in other ways. In particular, the state policy in this area boils down to the following: government subsidies for capital expenditures on housing construction, cheaper mortgage loans and easing the conditions for using them, influencing certain factors that determine construction costs, tax benefits. But, like other areas of government policy to regulate the economy in developed market countries, these measures are limited, ineffective, aimed mainly at direct and indirect subsidization of private-sector construction for wealthy categories of the population, at increasing the availability of housing for the middle classes and reduction of public spending on housing needs of the population, on curtailing the construction of apartments for low-income families.

Thus, along with the creation of promising and transitional types of residential buildings, it is already necessary to develop a set of measures related to the alteration of constructed residential buildings with regard to their subsequent rational use.

The problems of the national characteristics of modern housing in Azerbaijan are not independent, but constitute only the organic part of the big question about the creative focus of world housing as a whole. Therefore, the issues of national modern housing can be deeply scientifically covered only under the condition of their consideration from the position of the world dwelling as a whole.

\section{CONCLUSIONS}

The decision of housing problem on the modern stage comes true not only by building of dwelling-houses but also by the reconstruction of reorganization, modernization and major repairs of housing fund of old building and leading to of him to the level of standards and equipping with modern amenities of the modern dwelling. Providing of population a quality accommodation at corresponding price will come true with the use of next models: state-private partnership and executive model of public sector.

\section{REFERENCES}

[1]. Aaron H.J. Rational for a Housing Policy: Jacobs B.G., Harney K., Edson C. op.cit Struk R.J. Future U.S. Housing Policy

[2]. Buzuyev, V. and Chekalin V. (2016). Economy of the housing sphere. Moscow: INFRA-M

[3]. Calza A., Monaceelli T. and Stracca I. (2013) Housing Finance and Monetary policy. Journal of the European Economic Association, 11, pp.101-122

[4]. Danemark, B. and I.Blander (1994), Social Rented Sector in Europe: Policy. Tenure and Design, Delft University Press

[5]. Moskalyk, A. (2011). Public - private partnerships in housing and urban development. Nairobi: UN Habitat

[6]. O’Callivan А. Экономика города: 4-е издание/Пер. с англ.-іn.:ИНФРА, 2002

[7]. Saiz A. (2010). The Geographic Determinants of Housing Supply. Quarterly journal of Economics, 125(3), pp.1253-1296

[8]. Shulepina S., Govdja V. And Degaltseva G. (2016). Mechanisms for Improving the Functioning of the Subyects of housing and Communal Services in Russia. Applied Economics and Finance. 3(3) 